\title{
Maren Kraushaar
}

Germany

University of Maastricht

The European Union a stepping stone to further integration or rather a Eurocentric fortress?

Still with the memory of the destructive national power of the Second World War, the main initiators of the European integration stirred this project with the objective of preventing further conflicts through economic integration. Closer economic ties, spilling over to more countries and more policy areas lead to the development of an ever closer union which has become a powerful actor in international affairs. This essay will explore the question to what extent the European Union can be characterized as Eurocentric regionalism, rather focused on internal integration and enforcing outside borders than on global understanding. In order to shed light on this question several policy areas will be analysed, such as the European aid and trade policy, as well as the agricultural policy as these are areas where the European Union is directly confronted with external politics and international interests.

Taking a look at the European Union's aid policy in combination with its trade policy clearly shows the tension between its moral and humanitarian commitments in the framework of global responsibilities on the one hand and strong national interests and concerns on the other hand. The EU is one of the biggest donors in the world, adding all the national contributions from its member states, but is still lagging behind the promised 1, $27 \%$ of GNP. Moreover, when considered in relation to other figures, trade barriers remain high and create barriers for selfsustainability in developing countries. The EU is protecting its domestic market by high tariffs as well as subsidising its own production and depressing the world market price by dumping subsidized agricultural products on the world market. Not only Non-Governmental Organisations, such as Oxfam, criticised the EU trade policy, but also international organisations such as the World Trade Organisation ruled that the European Union is protecting its market in a discriminatory way. This is not in line with its commitment to liberalise trade and deconstruct trade barriers. Due to this international pressure, the European Union was forced to reform an agricultural sector that was not sustainable anymore. However, even under the reformed system, developing countries still face high entrance barriers and formerly supported sugar producers (under the Cotonou agreement of 2000) are forced out of business. Subsidies granted to European farmers are still higher than international aid donations. As Oxfam phrased it in its Make Trade Fair campaign " each European cow receives over two dollar a day in subsidies, well more than the daily income of half of the world's population" (Oxfam, 2005).

The demand for a fairer trade policy arose which would dismantle tariff barriers for developing countries and help them to develop a self-sufficient domestic industry and thus make them competitive on the world market, is constrained by internal interests. Even though there are agreements intended to support developing countries, these are often based on historical and political ties (such as the former French colonies which all benefit from the Cotonou agreement) issued for the African, Caribbean and Pacific countries (ACP). This juxtaposes the impression that aid, given by the multinational European Union, is donated out of international commitment 
and thinking. It is rather a colonial legacy and former established ties that influence aid distribution, thus alluding to a rather Eurocentric point of view.

However, in the media it is presented as altruistic humanitarian aid and, thus, alludes to an international thinking which sees the world as one human community falling under a global responsibility. This image is strengthened by the European Union' commitment to the Millennium Development Goals. On the other hand, the slow change and the reform under which unequal access still persists stresses to a Eurocentric perspective. Powerful farming lobbies, influential on the European policy level, ensure that subsidies are cut to a lesser extent and over a longer time frame. As one of the core policies introduced due to the demands of French farmers, it is almost impossible to reverse the adverse development in this policy field. A complete cut of subsidies would be impossible. A step in the right direction is undertaken with the introduction of environmental standards, the specialisation on biological produced food as well as decoupled payment. But on the other hand, this gives rise to the question that what extent is it fair that European citizens are able to choose and can afford biological grown products while developing countries are not even able to produce self-sufficiently, as it is impossible for them to build up a domestic processing industry as processed products face even higher tariffs.

While the original objectives of the Common Agricultural Policy were to provide a fair standard of living and to ensure a fair price to the consumer, the CAP does not meet these objectives anymore. As self-sufficiency has always been an argument, especially after the time of the Second World War, the situation today gives rise to the question if this kind of protectionism, which could also be called Eurocentrism, is still appropriate today. From an economic and political point of view, it is understandable that the European Union designed its policies to benefit its members first of all. Before calling it Eurocentric thinking, one has to keep in mind, that the redistribution of financial resources to support special areas such as agriculture, but also to support countries that are lagging behind with the creation of the Cohesion fund, shows besides economic considerations of creating a strong Europe which competitive with other global players, also a kind of European solidarity or at least a common vision for the future. However, this integration is pursued at the expense of weaker regions. While Europe is prospering and consciously struggling towards a community spirit by launching campaigns to forge a European identity, external borders are reinforced. The negative integration of creating a gap between "we" and the "other" is used to detract from internal disagreements. One may even claim that Europe's internal diversity is one of the reasons why it is so hard to form a common European identity so that a common "other" is needed to downplay internal diversity.

One other example is Schengen agreement. While it was made possible for EU citizens to move freely within the Schengen area, the same agreement enforced the external borders and made it even harder for non-EU citizens to enter. The same can be seen in the area of trade and aid. While on the one hand aid is given to developing countries, trade barriers remain high. Yet diminishing the trade barriers instead of giving a small amount of humanitarian aid would help the developing countries more. However, this would mean one opportunity less to present the EU in a positive light in international politics and on the other hand also mean a loss of control as active aid giving can be better managed than diminished trade barriers. Thus, Europe is eager to maintain its influence

This creates a gap between Europe and the "Other", namely the developing countries, by creating a dependency and the image of the EU going towards them to help the people and countries that do not possess the means themselves. Thus, instead of developing policies in which aid giving and aid receiving countries are equal partners and designing joint policies according to their needs, the developing countries are rather presented as the helpless, the "other", where "we" have to help. By this means of negative integration, one's own identity, in 
this case European identity, is strengthened by contrasting it to the "Other" (Woodward, 1996, p.124). This triggers a strong Eurocentric perspective, in which Europe is attributed with values of superiority, as it is Europe that is in the position to help the "Other". Rather than a humanistic approach of international thinking of human beings with the same needs, a distance is created between the starving far away and the prosperous union. This stands actually in contrast to the commitment to the Millennium Development Goals in which the goal number 8 stresses the need for a global partnership.

In conclusion, one could say that the European Union is not a stepping-stone to global integration, embracing more and more members. However, its internal organisation is still based on member states' interests and intergovernmental bargaining. While France is insisting on support for its farmers, Britain demands its rebate as its price for taking part in the European integration process. On a European scale, regarding the policy areas that have been integrated on European level over time and are still in the process of closer cooperation, this development was always also one of excluding the "Other". Rather than being motivated by international thinking and global responsibility, integration was characterized by personal motives and benefits for Europe itself. Taking the example of the aid sector, the EU managed to communicate a positive image as a donator, downplaying the fact, that trade barriers harm developing countries more than they benefit from EU aid.

\section{References}

Nello, S. (2005) The European Union: Economics, Policies and History. London: MacGrawHill

Oxfam. Make Trade Fair Campaign. Retrieved on March 22, 2006 from World Wide Web: http://www.maketradefair.com/en/index.php?file=issues sugar.htm

Woodward, K. (1997). Identity and Difference. Culture, Media and Identities. London: Sage/ The Open University 